\title{
Symphorien Champier, La Nef des dames vertueuses
}

\section{Michele Mastroianni}

\section{Q OpenEdition}

\section{Journals}

\section{Edizione digitale}

URL: http://journals.openedition.org/studifrancesi/9816

DOI: $10.4000 /$ studifrancesi.9816

ISSN: 2421-5856

\section{Editore}

Rosenberg \& Sellier

\section{Edizione cartacea}

Data di pubblicazione: 1 octobre 2007

Paginazione: 425

ISSN: 0039-2944

\section{Notizia bibliografica digitale}

Michele Mastroianni, «Symphorien Champier, La Nef des dames vertueuses», Studi Francesi [Online], 152 (LI | II) | 2007, online dal 30 novembre 2015, consultato il 07 janvier 2021. URL: http:// journals.openedition.org/studifrancesi/9816; DOI: https://doi.org/ERREUR PDO dans /localdata/ www-bin/Core/Core/Db/Db.class.php L.34 : SQLSTATE[HY000] [2006] MySQL server has gone away

Questo documento è stato generato automaticamente il 7 janvier 2021.

\section{(c) (i) (9)}

Studi Francesi è distribuita con Licenza Creative Commons Attribuzione - Non commerciale - Non opere derivate 4.0 Internazionale. 


\title{
Symphorien Champier, La Nef des dames vertueuses
}

\author{
Michele Mastroianni
}

\section{NOTIZIA}

SYMPHORIEN CHAMPIER, La Nef des dames vertueuses, édition critique par Judy KEM, Paris, Champion («Textes de la Renaissance», 114), 2007, pp. 307.

1 Pubblicata nel 1503, La Nef des dames, apologia femminista che si inserisce in una tradizione (di cui può essere considerata punto di arrivo) che risale al De claris mulieribus boccacciano e alla Cité des dames di Christine de Pizan, ha ora la sua prima edizione moderna (il solo quarto libro era stato pubblicato nel 1962). Essa consiste in quattro libri: il primo è una raccolta di biografie di clarae mulieres, secondo il modello di Boccaccio e di Christine; il secondo è un trattato sul matrimonio, in cui si offrono consigli morali e medici; il terzo contiene le profezie delle Sibille, tradotte a partire dal testo di Lattanzio e commentate; il quarto è un trattato sulla vraye amour, ricavato in buona parte dal Commento sul Convito di Platone di Marsilio Ficino. L'introduzione di J. Kem, oltre a offrire una notice biografica su Champier, analizza le modalità di inserimento dell'opera nella Querelle des femmes e le componenti del 'femminismo' di Champier, che, per quanto convinto dell'inferiorità delle donne, esorta gli uomini a trattarle da eguali. Interessante è il capitoletto consacrato all'Humanisme médical di Champier. Accurato e ricco il glossario, aggiornata la bibliografia. 